\title{
The Effects of Various Growth Temperatures on Nuclear Division, DNA and RNA in the Budding Yeast, Kluyveromyces fragilis
}

\author{
By C. S. PENMAN AND J. H. DUFFUS \\ Department of Brewing and Biological Sciences, \\ Heriot-Watt University, Edinburgh EHI I $H X$
}

(Received 30 January 1975; revised 23 April 1975)

\section{INTRODUCTION}

Most yeasts are able to multiply at or close to $0^{\circ} \mathrm{C}$ and have a maximum growth temperature within the range 30 to $40^{\circ} \mathrm{C}$. Phaff, Miller \& Mrak (I966) observed that Kluyveromyces fragilis (formerly Saccharomyces fragilis) does not fit into this general picture, having a minimum growth temperature of $5{ }^{\circ} \mathrm{C}$ and a maximum one of $45^{\circ} \mathrm{C}$. The present paper describes the effect of growth at $\mathrm{I} 5,30$ and $40{ }^{\circ} \mathrm{C}$ on batch cultures of $K$. fragilis.

\section{METHODS}

Organism and cultural conditions. Kluyveromyces fragilis (NCYCro0) was grown in $2 \%$ Oxoid malt extract broth at 15,30 and $40{ }^{\circ} \mathrm{C}$, with shaking at $\mathrm{I} 60 \mathrm{rev} . / \mathrm{min}$. Cultures were grown to the exponential growth phase at each temperature. Under these conditions, the yeasts had a doubling time of $160 \mathrm{~min}$ at $15{ }^{\circ} \mathrm{C}, 90 \mathrm{~min}$ at $30^{\circ} \mathrm{C}$ and $\mathrm{I} 20 \mathrm{~min}$ at $40^{\circ} \mathrm{C}$. Cell number determinations were carried out using a Thoma haemocytometer. (Duffus \& Penman, 1973).

Cytochemical and biochemical methods. The time of nuclear division was determined in cells grown at each temperature following Giemsa staining, as described by Duffus \& Penman (1973). DNA was estimated in cultures grown at each temperature following the method of Bostock (1970). RNA was estimated using the orcinol method (Mejbaum, 1939).

\section{RESULTS}

At $15{ }^{\circ} \mathrm{C}, 14.7 \%$ of cells contained two nuclei. At $30{ }^{\circ} \mathrm{C}$ this figure was $32 \%$ and at $40{ }^{\circ} \mathrm{C}$ it was $20.14 \%$. Therefore at $15{ }^{\circ} \mathrm{C}$, nuclear division occurs at a point 0.80 of the cycle from cell division to division; at $30{ }^{\circ} \mathrm{C}$ this point occurs at 0.60 of a cycle, and at $40{ }^{\circ} \mathrm{C}$ at 0.74 of a cycle after cell division. The times between nuclear division and cell division are therefore $32 \mathrm{~min}$ at $15{ }^{\circ} \mathrm{C}, 36 \mathrm{~min}$ at $30^{\circ} \mathrm{C}$ and $32 \mathrm{~min}$ at $40^{\circ} \mathrm{C}$.

Table I shows the generation time for each growth temperature, the DNA and RNA contents per cell, and the ratio of RNA to DNA. The relationship between the RNA to DNA ratio and the generation time was remarkably constant. At $15{ }^{\circ} \mathrm{C}$ it was $\mathrm{I} \cdot 05$, at $30^{\circ} \mathrm{C} \mathrm{I} \cdot 20$, and at $40^{\circ} \mathrm{C}$ it was $\mathrm{I} \cdot \mathrm{I} 5$. There is less DNA per cell at $15^{\circ} \mathrm{C}$ than at the higher growth temperatures.

\section{DISCUSSION}

It should be noted that the above calculation of the time of nuclear division depends on the assumption that the growth rates of individual cells increase exponentially over the cell cycle (see Mitchison, I97I). If this is true, we have a system where the time between nuclear division and cell division is constant and independent of temperature. Any straightforward 
Table I. Generation times, and DNA and RNA contents of exponentially-growing cells of $K$. fragilis in asynchronous cultures at different growth temperatures

\begin{tabular}{lccc} 
& \multicolumn{3}{c}{ Growth temperature } \\
\cline { 2 - 3 } & $15{ }^{\circ} \mathrm{C}$ & $30^{\circ} \mathrm{C}$ & $40^{\circ} \mathrm{C}$ \\
Generation time (min) & 160 & 90 & 120 \\
$10^{14} \times$ DNA/cell (g) & 4.40 & $6 \cdot 15$ & 6.40 \\
$10^{12} \times$ RNA/cell (g) & $7 \cdot 40$ & 6.57 & $8 \cdot 80$ \\
RNA:DNA & $168: 1$ & $108: 1$ & $138: \mathrm{I}$ \\
RNA/DNA:generation & $1 \cdot 05$ & $1 \cdot 30$ & $1 \cdot 15$ \\
time & & &
\end{tabular}

chemical system involved in linking nuclear and cell division should show a marked temperature dependence. Consequently one must postulate a more complex system. At its very simplest, such a system would have to involve two reactions, one, initiated by nuclear division, controlling the synthesis of a product necessary for cell division, the other controlling its breakdown. Both of these reactions would have to have equal thermal coefficients.

The apparent constancy of the relationship between the RNA and DNA ratio and generation time is puzzling, and at present no explanation is available to account for this observation. In our results, it reflected a change in the total RNA per cell and, in the $15{ }^{\circ} \mathrm{C}$ culture, a decrease in the total amount of DNA per cell. This is surprising because we have previously established (Duffus \& Penman, 1973) that the S period of $K$. fragilis is nearly coincident with the time of cell division at $30^{\circ} \mathrm{C}$. Hence, any lowering of the total amount of DNA per cell cannot be explained simply on the basis of the $\mathrm{G}_{2}$ period (the period between the DNA synthetic period, $\mathrm{S}$, and the period of cell division) being reduced. The $30{ }^{\circ} \mathrm{C}$ figure must approximate to the $2 \mathrm{c}$ amount of DNA at that temperature and therefore the $15{ }^{\circ} \mathrm{C}$ figure represents a marked reduction in the $2 \mathrm{c}$ amount of DNA. A possible explanation of the phenomenon is that, at the higher temperatures, one or more of the chromosomes may be replicated more than once during the $S$ period. If this is so, we have a situation analogous to that in Escherichia coli where short generation times are characterized by more than one replicating chomosome being present per cell, i.e. generation time is related to the frequency with which replication forks are initiated. Possibly other simple eukaryotes will show the same property. If so, it would be interesting to observe whether there is any correlation with the near absence of histones, as in yeast where only the f2a2 fraction appears to be present (Franco, Johns \& Navlet, 1974; Penman and Duffus, unpublished).

We thank the S.R.C. for a research studentship to C.S.P. and for grant No. B/RG/06526 to J.H.D. We are also grateful to Professor D. J. Manners for providing post-doctoral funds for C.S.P.

\section{REFERENCES}

Bostock, C. J. (1970). DNA synthesis in the fission yeast Schizosaccharomyces pombe. Experimental Cell Research 60, 16-26.

Duffus, J. H. \& Penman, C. S. (1973). Stepwise accumulation of an acid-extractable protein fraction in the budding yeast, Kluyveromyces fragilis, during the cell cycle. Journal of General Microbiology 79, I 89-194.

Franco, L., Johns, E. W. \& NAVLET, J. M. (I974). Histones from baker's yeast. Isolation and fractionation. European Journal of Biochemistry 45, 83-89.

Mejbaum, W. (1939). Estimation of small amounts of pentose, especially in derivatives of adenylic acid. Zeitschrift für physiologische Chemie 258, $117-120$.

Mrtchison, J. M. (I97I). The Biology of the Cell Cycle. Cambridge: Cambridge University Press.

Phaff, H. J., Miller, M. W. \& MraK, E. M. (1966). The Life of Yeasts. Cambridge, Massachusetts: Harvard University Press. 